Aldermanbury. Ten years later he was elected President of the Chartered Insurance Institute itself. His year of office, I94I-42, was rather a barren one because during the War much of the work of that Institute was suspended and no annual conference was held.

His connexion with general insurance education was a good influence and caused some actuaries to take a wider view of their field of activities. It is worth noting that Sir William Elderton was his successor in the Presidency of the Chartered Insurance Institute.

While he made his business and his career therein of first importance, that did not absorb his entire energies. During the active portion of his life he was a keen golfer and seldom missed those weekend golf meetings in which insurance men have delighted. In such gatherings he was popular: he was a good mixer and it was only natural that he found himself elected to the chair of the two senior actuarial dining clubs-the Actuaries and the Gallio.

Workman had no gift of rhetoric but he could get over what he had to say without the frequent use of notes, and in an ordered manner, drawing on an excellent memory for the headings to which he wished to refer. He delighted in hospitality and was an excellent host to those friends who had the pleasure of dining with him at his clubs, the Union and the Reform. Unfortunately many of his personal friends who had travelled the road with him had left it before him, so that in the last few years their absence and his own ill health limited him, but not unhappily, to his home circle of wife, daughter and grandson.

H. E. R.

\title{
PERCY CHARLES CRUMP
}

By the death on Friday, 25 May 1956, of Percy Charles Crump, O.B.E., F.I.A., the insurance world and the Institute of Actuaries lost one of their most worthy members.

Crump entered the service of the Prudential Assurance Company in 1895 . He qualified as a Fellow of the Institute of Actuaries in I909, and in the course of a distinguished career became Joint Secretary of his Company in 193I. He remained Joint Secretary until his retirement in 1942 when he was elected a Director, and served on the Board until he retired through ill health in 1953 .

He was awarded the O.B.E. for his services in connexion with the American Dollar Securities Committee during the First World War. This Committee was responsible for the mobilization and management of securities valued at thousands of millions of dollars. In 1928 he contributed a paper to the Institute of Actuaries on the financial conditions during and after the 1914-18 War as they affected life assurance companies.

These brief biographical details, however, give no clue to the character or stature of the man himself. It was not in Crump's nature to court publicity. A true assessment of him as a person, therefore, can only be made by those who knew him well, and as one who was intimately associated with him for very many years I am, perhaps, as well qualified as any to make this assessment. I can best present a picture of him by quoting a couplet by Alexander Pope, and describe him as-

By nature honest, by experience wise, Healthy by temperament and by exercise. 
His career was not spectacular but it was built on the foundation of complete probity and integrity and was, therefore, one of solid achievement. $\mathrm{He}$ possessed in full measure those qualities, including a kind of innate philosophy, from which real values spring and which make a man a worthy member of the community. He was forceful in argument, indeed somewhat blunt of tongue, but lacked nothing in kindness or in tolerance. He was respected for the independence of his judgment in business matters, and leading people in the City and elsewhere came to have very great respect for his financial acumen.

He took a life-long interest in sport of all kinds and, in particular, in athletics. He was no mean runner in his day. He helped to found the Insurance Athletic Association and was, in fact, attending amateur athletic meetings right up to the time of his death.

Above all, he was intensely loyal to the Company that he served and was ever watchful of the interests of the staff who served under him and who, without exception, regarded him with affection. In this respect, it was typical of the man that in his will he left a present to those who were on his staff at the date of his retirement, who had served for five years previously and who were still alive at the time of his death.

For all these reasons he will long be remembered by his personal friends and by his business colleagues. He has left this world, but his influence will remain.

E. H.L.

\section{JOHN ARTHUR JEFFERSON}

ON 2 November 1956, at the age of 73, John Arthur Jefferson died of a heart attack after a long period of indifferent health. Born at West Bromwich, he was the son of Frederick Thomas Jefferson, a prominent business man of that town.

After being educated at King William's College, Isle of Man, Jefferson worked successively in a chartered accountant's office, a stockbroker's office, and T. G. Ackland's office, and studied for the Institute examinations. In 1906 he joined the staff of the Britannic as Assistant Secretary, and became Secretary in I9I0 on qualifying as a Fellow. He was appointed General Manager in 1916 and became, additionally, Chairman of the Company in 1924. $\mathrm{He}$ thus held executive office for over $5^{\circ}$ years, and for 44 of those years he worked in close association with the late James Murray Laing. They formed a very fine combination, and the Company made great progress. To commemorate Jefferson's 50 years of service, the Company's staff subscribed for a portrait by Frank Salisbury, which was unveiled and hung in the Board Room in May 1956.

Jefferson had an exceptionally fine physique, and during his residence in London captained Rosslyn Park and represented Middlesex at rugby football. He was a useful cricketer and tennis player, had a low golf handicap and in later life enjoyed shooting, yachting and photography; but his main interest was his business, at which he worked hard.

Apart from his managerial duties including the management of a very large indoor and outdoor staff, he had a natural flair for investment work, and long before it became fashionable he invested shrewdly and successfully in equity shares. He was interested in staff welfare, and took a leading part in the provision of sports facilities and the setting up of the Company's staff and widows' pension funds. Although never engaged on the actuarial side of the 